\title{
Solidification/Stabilization of Fly Ash from a Municipal Solid Waste Incineration Facility Using Portland Cement
}

\author{
Qiang Tang, ${ }^{1,2,3}$ Yang Liu, ${ }^{1}$ Fan Gu, ${ }^{4}$ and Ting Zhou' \\ ${ }^{1}$ School of Urban Rail Transportation, Soochow University, Soochow, China \\ ${ }^{2}$ Key Laboratory of Ministry of Education for Geomechanics and Embankment Engineering, Hohai University, Nanjing, China \\ ${ }^{3}$ Jiangsu Research Center for Geotechnical Engineering Technology, Hohai University, Nanjing, China \\ ${ }^{4}$ Texas A\&M Transportation Institute, Texas A\&M University, College Station, TX, USA
}

Correspondence should be addressed to Fan Gu; tracygufan@tamu.edu

Received 10 April 2016; Accepted 8 September 2016

Academic Editor: Jun Liu

Copyright (C) 2016 Qiang Tang et al. This is an open access article distributed under the Creative Commons Attribution License, which permits unrestricted use, distribution, and reproduction in any medium, provided the original work is properly cited.

\begin{abstract}
This study investigated the solidification/stabilization of fly ash containing heavy metals using the Portland cement as a binder. It is found that both the cement/fly ash ratio and curing time have significant effects on the mechanical (i.e., compressive strength) and leaching behaviors of the stabilized fly ash mixtures. When the cement/fly ash ratio increases from $4: 6$ to $8: 2$, the increase of compressive strength ratio raises from $42.24 \%$ to $80.36 \%$; meanwhile, the leaching amount of heavy metals decreases by $2.33 \%$ to $85.23 \%$. When the curing time increases from 3 days to 56 days, the compressive strength ratio of mixtures raises from $240.00 \%$ to $414.29 \%$; meanwhile, the leaching amount of heavy metals decreases by $16.49 \%$ to $88.70 \%$. The decrease of compressive strength with the lower cement/fly ash ratios and less curing time can be attributed to the increase of fly ash loading, which hinders the formation of ettringite and destroys the structure of hydration products, thereby resulting in the pozzolanic reaction and fixation of water molecules. Furthermore, the presence of cement causes the decrease of leaching, which results from the formation of ettringite and the restriction of heavy metal ion migration in many forms, such as C-S-H gel and adsorption.
\end{abstract}

\section{Introduction}

Incineration, as an effective method to energy recovery and reduction of the volume and weight of waste, has been widely adopted for the treatment of solid waste around the world $[1,2]$. According to the Eurostat yearbook, the incineration percentages of solid waste in Germany and France were as high as $32 \%$ [3]. In Holland, the incineration percentage of solid waste already reached $40 \%$ in 2000 , while such incineration percentage was around $60 \%$ in Sweden, Denmark, and Luxembourg, even up to $77 \%$ and $80 \%$ in Japan and Switzerland $[4,5]$. During the incineration process, heavy metals in the waste were accumulated through absorption by fly ash along the evaporation of the water and the decrease in waste volume, and the concentration of heavy metals eventually reaches a relative high level. The heavy metal contents of fly ash from various districts worldwide are detailed in Table 1 . The upper limits of designated heavy metals in soils, defined by three listed standards individually implemented by European union, Canada, and China, are also shown in Table 1. Thus, fly ash is regarded as hazardous waste in Code 19.01.13 of the Council of the European Union and has to be pretreated according to ASTM STP 1123 and 40 CFR 261.24 [1,6-8]. Similar to pozzolana, the composition of fly ash also includes high content of Si and $\mathrm{Ca}$, which provide the potential possibility for further utilization, such as cement and concrete products, structural fill, cover material, and roadway and pavement utilization [9]. In Germany, 50\% of the ash produced from the incinerated waste was used in the manufacture of sound insulating walls along highways and the sublayers of city roads. In Denmark, over $72 \%$ of the ash is reused in the construction of parking lots, cycling tracks, and other roads [10].

For the reutilization in the civil and environmental engineering fields, the fly ash should meet the requirement in both the mechanical and leaching properties of heavy metals. According to Choi et al. and Song et al.'s research, cement can be utilized as a binder to effectively reduce the leachability 
TABLE 1: Heavy metals in fly ash from various districts and countries.

\begin{tabular}{|c|c|c|c|c|c|c|c|c|}
\hline & \multicolumn{7}{|c|}{ Heavy metal content (mg/kg) } & \multirow{2}{*}{ References } \\
\hline & $\mathrm{Cr}$ & $\mathrm{Pb}$ & $\mathrm{Cu}$ & $\mathrm{Zn}$ & $\mathrm{Cd}$ & $\mathrm{Ni}$ & $\mathrm{Hg}$ & \\
\hline \multicolumn{9}{|l|}{ Standard } \\
\hline EU & 100 & 100 & 100 & 300 & 1 & 50 & - & {$[20]$} \\
\hline CCME & 64 & 70 & 63 & 200 & 1.4 & 50 & - & {$[21]$} \\
\hline $\mathrm{GB}$ & 150 & 280 & 50 & 200 & 0.3 & 70 & 0.25 & {$[22]$} \\
\hline \multicolumn{9}{|l|}{ China } \\
\hline Wuhan & 282 & 1276 & 899 & 4187 & 36 & - & - & {$[23]$} \\
\hline Shanghai & 180 & 2710 & 990 & 4530 & 90 & 70 & - & {$[24]$} \\
\hline Shenzhen & 566.2 & 1356.4 & 3080.8 & 37383.5 & 77.8 & 1583.9 & - & {$[25]$} \\
\hline Spain & 790 & 398 & 156 & 15900 & $\leq 6$ & 90 & $<60$ & {$[2]$} \\
\hline Poland & 152.9 & 185.7 & 240.0 & 4660.0 & 87.5 & 78.6 & - & [26] \\
\hline Japan & 235 & 3750 & 1800 & 21000 & 225 & - & 4.5 & [27] \\
\hline Portugal & 185 & 2462 & 586 & - & 83.4 & 61 & - & [28] \\
\hline Italy & 109 & 964 & 173 & - & 85 & 45 & - & [29] \\
\hline Denmark & 99.0 & 2710 & 749.1 & 22400 & 97.6 & - & - & [30] \\
\hline Austria & 500 & 4500 & 890 & 19000 & 350 & 94 & - & {$[31]$} \\
\hline India & 120 & 35 & 100 & - & - & 150 & - & {$[32]$} \\
\hline Belgium & 100 & 2900 & 500 & 9400 & 300 & 100 & $<100$ & {$[33]$} \\
\hline
\end{tabular}

Note: EU = European Union Standards (2009); CCME = Canadian Environmental Quality Guidelines (1999); GB = Environmental Quality Standards for Soils of China (2009).

of $\mathrm{As}$ and $\mathrm{Pb}$ in mine tailing [11-14]. Furthermore, Voglar and Leštan's and Patel and Pandey's findings indicated that, with the presence of cement in sludge and contaminated soils, the mechanical properties (i.e., compressive strength) were also greatly improved $[15,16]$. Considering all above, in this study, the ordinary Portland cement (OPC) was selected as a binder material utilized for the solidification/stabilization (S/S) treatment towards the fly ash. Compressive strength test and TCLP (Toxicity Characteristic Leaching Procedure) tests were conducted to the cement-stabilized fly ash mixtures. This study investigated the mechanical behavior of the mixtures and the leaching behaviors of heavy metal ions (e.g., $\mathrm{Cr}, \mathrm{Cd}, \mathrm{Pb}, \mathrm{Ni}, \mathrm{Cu}$, and $\mathrm{Mn}$ ). The influence factors taken into account in this study include the cement/fly ash ratio, moisture content, fly ash-water reaction, and curing time. Visual MINTEQ was used to simulate the experimental conditions. The calculation results were used to analyze the leaching behaviors of heavy metals. Based on the calculation results, further discussions were made towards the S/S mechanisms and the leaching behaviors of heavy metals with the assistance of X-ray diffraction (XRD) pattern and X-ray fluorescence (XRF) results.

\section{Materials and Methods}

2.1. Materials. Since incineration can provide a substantial reduction in volume and weight of the waste, landfills usually equipped incineration facilities to cut down the cost of waste disposal. The fly ash used in this study was collected from municipal solid waste (MSW) incineration facility in the Qizi Mountain landfill site, Suzhou, China. The landfill has a total storage capacity of 4.7 million $\mathrm{m}^{3}$. Approximately 5000

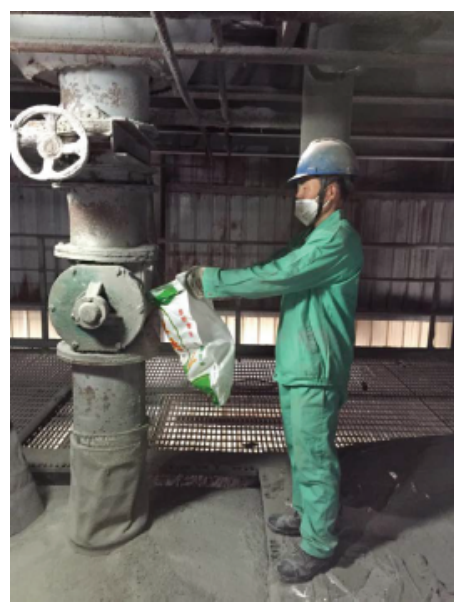

FIGURE 1: MSWI fly ash sample collection.

tons (t)/day of MSW was deposited at this location. Among them, around $3550 \mathrm{t} / \mathrm{day}$ MSW was incinerated for electricity generation, and the incineration temperature inside the incinerator was controlled at $900^{\circ} \mathrm{C}-1100^{\circ} \mathrm{C}$. During the incineration, the flue gases were successively purified by an alkaline absorbent spray system (acid gases removal), an activated carbon injection system (heavy metals and dioxin removal), and a fabric filter (dust removal and fly ash generation). In Qizi Mountain landfill site, over 100 t/day fly ashes were produced during MSW incineration. With the assistance of the staff there, original fly ash samples utilized in this study were collected as shown in Figure 1. As the binder material, the commercially available OPC P.O 42.5 was prepared, which consisted of $6 \%-15 \%$ active additive and $85 \%-94 \%$ cement. 
$\mathrm{N}_{2}$-BET adsorption tests were conducted on fly ash to analyze several parameters, including the specific surface area, total pore volume, micropore volume (diameter $<102.12 \mathrm{~nm}$ ), and average pore size (NOVA2000e, Quantachrome, US). Moisture content and water retention capacity were measured following JIS A 1203 and JGS 0151, respectively [17]. The maximum and minimum density and the granule density of the fly ash were determined according to JGS 0162, JIS A 1224, and JIS A 1202, respectively [17]. Plastic limit was determined according to JIS A 1205 [17]. Following GB/T50123-1999, liquid limit was determined by Photoelectric Liquid-Plastic Tester (GYS-2, Turangyiqi, China) [18]. In accordance with JIS A 1218, hydraulic conductivity was determined using a permeameter (TST-55, Jingkeyusheng, China) [17]. In addition, swell index and grain size distribution test of fly ash were conducted according to ASTM D5890-06 [19] and GB/T50123-1999 [18], respectively. The chemical composition and mineral composition of fly ash and OPC were analyzed by XRF (JSX-3400R, JEOL, Japan) and XRD (RAD-2B, Rigaku Corporation, Japan). The electrical conductivity (EC) and $\mathrm{pH}$ of the samples were measured using a $\mathrm{pH} / \mathrm{EC}$ meter (PH-2603, Lohand, China), following JGS 0212 and JGS 0211, respectively [17].

2.2. Preparation of Samples. Fly ash and OPC samples were oven dried at $105^{\circ} \mathrm{C}$ for 24 hours (h) (101-A, Leao, China) to ensure the accurate quality during the experiment, since there might be some moisture content in them. Subsequently, they were cooled to room temperature in a desiccator. In order to mix evenly, the fly ash was first homogenized with the cement at five different ratios of cement/fly ash $(8: 2,7: 3,6: 4,5: 5$, and $4: 6$ by dry mass) manually for $4-5$ minutes ( $\mathrm{min}$ ) in the vessel [1]. Then distilled water, which was produced by a water distillation apparatus (JYCS-0.02T, China), was added slowly into the dry mix for the mixing process.

To determine the optimum water content or water/cement ratio, two preliminary tests were carried out as follows. Fly ash was mixed with water with the initial moisture contents maintained at $42.86 \%, 66.67 \%, 100 \%, 150.00 \%$, $233.33 \%$, and $400 \%$ (preliminary test 1 ); $10 \%, 20 \%, 30 \%$, $40 \%, 50 \%, 60 \%, 70 \%, 80 \%, 90 \%$, and $100 \%$ (preliminary test 2). During the test period, one mixture was exposed to the air in preliminary test 1 ; meanwhile another mixture was sealed by a polyethylene membrane in preliminary test 2. Then the final moisture contents were determined after $15 \mathrm{~min}$ (preliminary test 1 ) and $6 \mathrm{~h}$ (preliminary test 2), and the results are presented in Figures 2 and 3, respectively. From Figure 2, the initial water content decreased by $2.78 \%-$ $13.00 \%$ within $15 \mathrm{~min}$, which indicates that $3.25 \%-6.67 \%$ water evaporated due to the heat released by the reaction between fly ash and water. In preliminary test 1 , the reaction between water and fly ash was neglected since the relative short period. As shown in Figure 3, the initial water content decreased by $4.17 \%-11.0 \%$ after $6 \mathrm{~h}$, which indicates $7.22 \%-$ $53.00 \%$ water has reacted with fly ash. Since the samples were all sealed by a polyethylene membrane during experiment period, the evaporation can be neglected in preliminary test 2 . Considering the above and the hydration reaction of cement, the water-cement ratio was therefore maintained at $1: 1$.

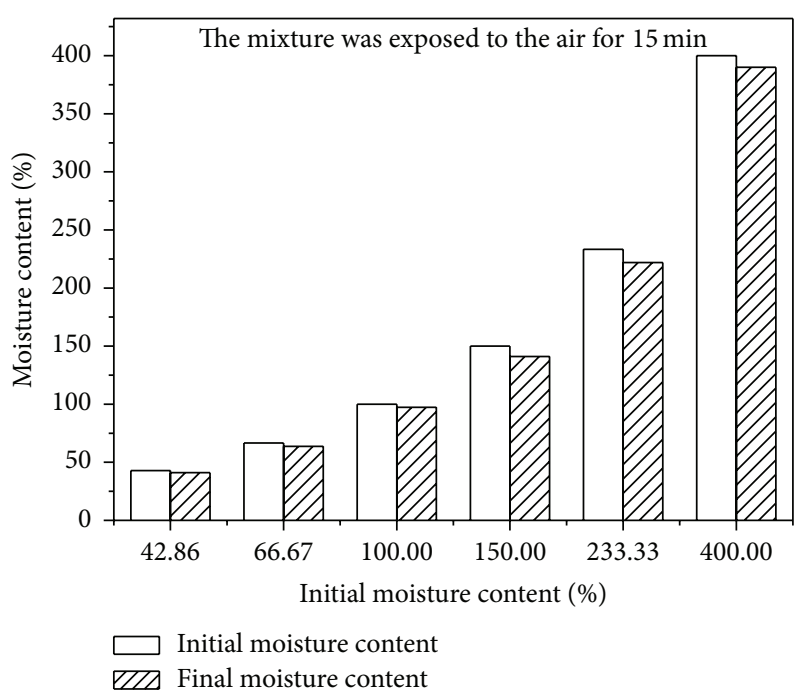

FIgURE 2: Moisture content before and after preliminary test 1.

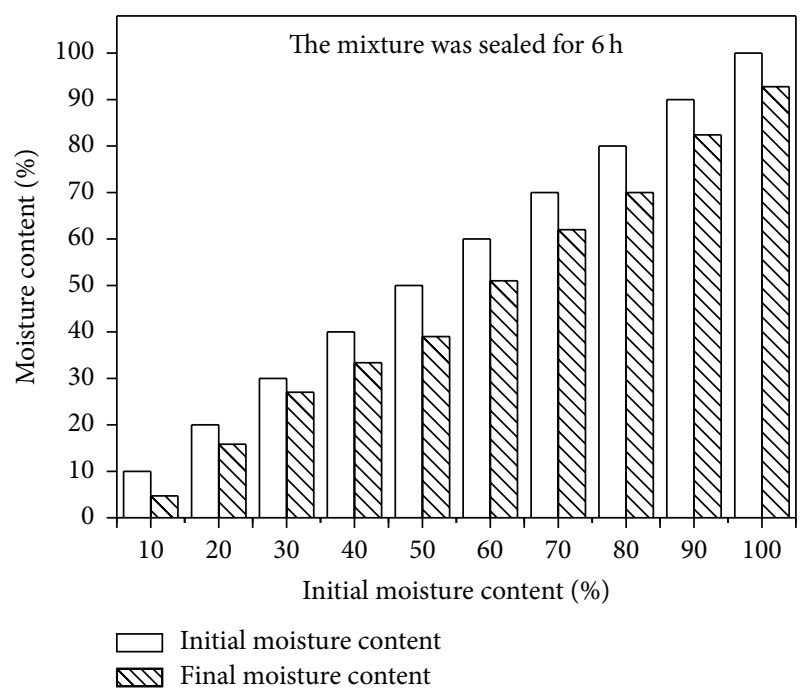

Figure 3: Moisture content before and after preliminary test 2.

After the mixing procedure, the mixture was transferred into the moulds $(100 \mathrm{~mm} \times 100 \mathrm{~mm} \times 100 \mathrm{~mm}$, Jianyi, China), which were then sealed with a polyethylene membrane to avoid severe dehydration. Afterwards, the mixtures were left undisturbed for $24 \mathrm{~h}$ at room temperature $\left(23 \pm 2^{\circ} \mathrm{C}\right)$ and high relative humidity $(>50 \%)$. Three replicates were analyzed for each trial. After the period of the initial setting, the mixtures were demoulded and cured ( $\geq 95 \%$ humidity, $20 \pm 2^{\circ} \mathrm{C}$ ) for 3 , $7,14,28$, and 56 days in a curing box (HBY-15B, Donghua, China).

2.3. Compressive Strength Test Method. Microcomputer Controlled Electronic Testing Machine (LDS-50, Chenda, China) was used to obtain the compressive strength of samples. The loading platform's diameter was $15 \mathrm{~cm}$ and the range was fixed at $0-30 \mathrm{kN}$ during the test. Total maximum loads were recorded at the point of fracture and the compressive strength was determined using the formula $P=F / A$, where $P$ is 
TABLE 2: Properties of fly ash.

\begin{tabular}{|c|c|c|c|}
\hline Property & Units & Standard & Values \\
\hline Moisture content & $\%$ & JIS A 1203 & 6.110 \\
\hline Water retention capacity & $\%$ & JGS 0151 & 117.8 \\
\hline Maximum density & $\mathrm{g} / \mathrm{cm}^{3}$ & JGS 0162 & 0.67 \\
\hline Minimum density & $\mathrm{g} / \mathrm{cm}^{3}$ & JIS A 1224 & 0.49 \\
\hline Granule density & $\mathrm{g} / \mathrm{cm}^{3}$ & JIS A 1202 & 2.528 \\
\hline Plastic limit & $\%$ & JIS A 1205 & 15.96 \\
\hline Liquid limit & $\%$ & GB/T50123-1999 & 47.66 \\
\hline Swell index & $\mathrm{mL} / 2 \mathrm{~g}$-solid & ASTM D 5890-06 & 3.00 \\
\hline Hydraulic conductivity & $\mathrm{m} / \mathrm{s}$ & JIS A 1218 & $1.55 \times 10^{-7}$ \\
\hline $\mathrm{pH}$ & - & JGS 0211 & 12.15 \\
\hline $\mathrm{EC}$ & $\mathrm{mS} / \mathrm{cm}$ & JGS 0212 & 57.68 \\
\hline Grain size distribution & & GB/T 50123-1999 & \\
\hline Sand fraction $(2-0.075 \mathrm{~mm})$ & $\%$ & & 12.10 \\
\hline Silt fraction $(0.075-0.005 \mathrm{~mm})$ & $\%$ & & 84.26 \\
\hline Clay fraction $(\leq 0.005 \mathrm{~mm})$ & $\%$ & & 3.64 \\
\hline Uniformity coefficient & - & & 4.02 \\
\hline Coefficient of curvature & - & & 1.12 \\
\hline \multicolumn{4}{|l|}{$\mathrm{N}_{2}$-BET } \\
\hline Correlation coefficient $\left(R^{2}\right)$ & - & & 0.999 \\
\hline Specific surface area & $\mathrm{m}^{2} / \mathrm{g}$ & & 7.944 \\
\hline Average pore size & $\AA$ & & 114.2 \\
\hline Total pore volume & $\mathrm{mL} / \mathrm{g}$ & & $2.710 \times 10^{-2}$ \\
\hline $\begin{array}{l}\text { Micropore volume (diameter < } \\
102.12 \mathrm{~nm} \text { ) }\end{array}$ & $\mathrm{mL} / \mathrm{g}$ & & $2.516 \times 10^{-2}$ \\
\hline
\end{tabular}

the compressive strength $(\mathrm{MPa}), F$ is the total maximum load $(\mathrm{N})$, and $A$ is the area of loaded surface $\left(\mathrm{mm}^{2}\right)[34,35]$. All of samples were prepared in triplicate.

2.4. Leaching Test Method for Heavy Metals. First of all, the extraction buffer was prepared using $1 \mathrm{~mol} / \mathrm{L}$ acetic acid and $1 \mathrm{~mol} / \mathrm{L}$ sodium hydroxide $(\mathrm{pH} 2.88 \pm 0.05)$. The crushed samples collected after the compressive strength test were oven dried at $105^{\circ} \mathrm{C}$ for $24 \mathrm{~h}$. Then the dried samples were further crushed manually until the particle size was less than $9.5 \mathrm{~mm}$. The crushed samples were then leached using the previously prepared extraction buffer at a liquid/solid ratio of $20: 1$. Subsequently, the extraction was performed using Flip-Automatic Extraction Oscillator (KB-W08, Marina Bay, China) for $18 \pm 2 \mathrm{~h}$ at $23 \pm 2^{\circ} \mathrm{C}$ and the rotational speed was fixed at $30 \pm 2 \mathrm{r} / \mathrm{min}$. After the extraction, the leachate samples were filtered through a $0.45 \mu \mathrm{m}$ borosilicate glass fiber filter and the resultant TCLP (US EPA Test Method 1311) extract (filtrate) was analyzed for heavy metals by Atomic Absorption Spectroscopy (AAS) (TAS-990, Persee General, China) [36]. All the samples were prepared in duplicate.

\section{Results and Discussion}

3.1. Characterization of the Materials. The properties of fly ash are detailed in Table 2. As shown in Table 2, the moisture content of fly ash is $6.110 \%$. The maximum and minimum density are 0.67 and $0.49 \mathrm{~g} / \mathrm{cm}^{3}$, respectively. The granule density of fly ash is $2.528 \mathrm{~g} / \mathrm{cm}^{3}$, which is lower than that of the clay utilized in Tran et al. (i.e., the granule density of fly ash is $2.7 \mathrm{~g} / \mathrm{cm}^{3}$ ) [37]. The plastic limit and liquid limit of fly ash are $15.96 \%$ and $47.66 \%$, respectively. The swell index is $3.00 \mathrm{~mL} / 2 \mathrm{~g}$ solid, almost the same as the Fukakusa clay utilized in Tang et al., which demonstrates that the fly ash used in the experiment contains little expansive constitute [38]. As observed in the grain size accumulation curve of fly ash presented in Figure 4, the curve is steep when the particle size ranges from 0.067 to $0.1 \mathrm{~mm}$, which indicates that the particle size distribution is dense within this range. The uniformity coefficient and coefficient of curvature are 4.02 and 1.12, respectively [39]. This indicates that the particle size distribution is relatively uniform. The hydraulic conductivity of fly ash is $1.55 \times 10^{-7} \mathrm{~m} / \mathrm{s}$, two orders of magnitude higher than that of the clay used in Tran et al. [37]. The diverse hydraulic conductivities can be attributed to the difference in the particle size. The $\mathrm{pH}$ value of fly ash is 12.15 because of its alkaline nature. The EC value of fly ash is $57.68 \mathrm{mS} / \mathrm{cm}$, which is 287 times higher than for the soil used in Taghipour and Jalali [40]. This demonstrates that a large amount of soluble salt exists in fly ash and thus increases the difficulty in immobilization.

The specific surface area of the fly ash used in this experiment is $7.944 \mathrm{~m}^{2} / \mathrm{g}$. This is much higher than the pozzolana utilized in Ghrici et al., which is $0.42 \mathrm{~m}^{2} / \mathrm{g}$ [41]. 


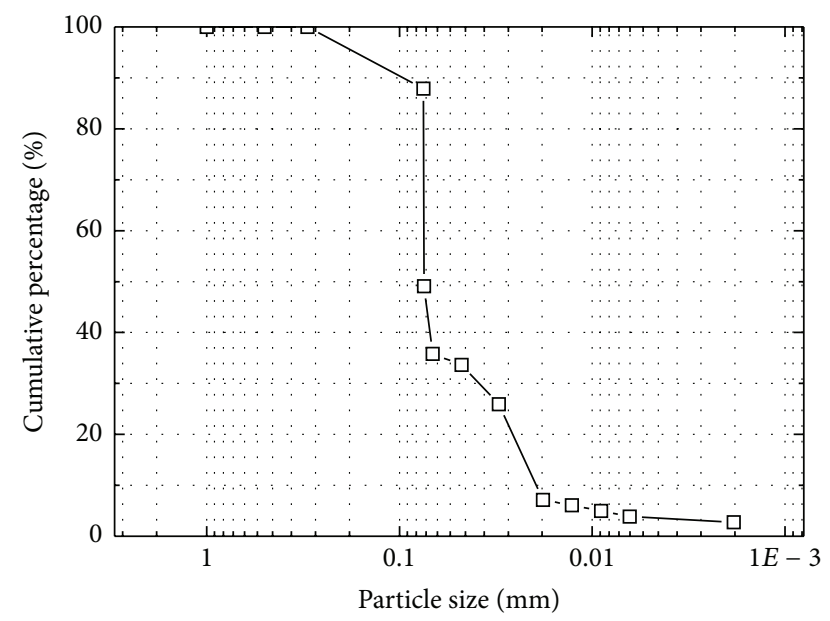

FIgURE 4: Grain size distribution curve of fly ash.

TABLE 3: Chemical compositions of fly ash and OPC.

\begin{tabular}{|c|c|c|c|}
\hline Chemical composition & Unit & Fly ash & OPC \\
\hline $\mathrm{SiO}_{2}$ & $\%$ & 11.53 & 20.85 \\
\hline $\mathrm{Al}_{2} \mathrm{O}_{3}$ & $\%$ & 7.89 & 5.71 \\
\hline $\mathrm{Fe}_{2} \mathrm{O}_{3}$ & $\%$ & 2.57 & 3.33 \\
\hline $\mathrm{CaO}$ & $\%$ & 41.80 & 60.48 \\
\hline $\mathrm{MgO}$ & $\%$ & 2.27 & 2.28 \\
\hline $\mathrm{SO}_{3}$ & $\%$ & 3.25 & 2.84 \\
\hline $\mathrm{Na}_{2} \mathrm{O}$ & $\%$ & 2.58 & 1.43 \\
\hline $\mathrm{K}_{2} \mathrm{O}$ & $\%$ & 5.74 & 0.73 \\
\hline $\mathrm{TiO}_{2}$ & $\%$ & 0.68 & 0.31 \\
\hline $\mathrm{Cl}$ & $\%$ & 10.89 & 0.26 \\
\hline $\mathrm{ZnO}$ & $\%$ & 1.30 & - \\
\hline $\mathrm{PbO}$ & $\%$ & 0.55 & - \\
\hline $\mathrm{CdO}$ & $\%$ & 0.07 & - \\
\hline $\mathrm{MnO}$ & $\%$ & 0.07 & - \\
\hline $\mathrm{CuO}$ & $\%$ & 0.25 & - \\
\hline $\mathrm{Cr}_{2} \mathrm{O}_{3}$ & $\%$ & 0.01 & - \\
\hline
\end{tabular}

This may be because the particle size of fly ash is smaller than that of the pozzolana. In addition, the specific surface area of the fly ash is smaller than that of the bentonite utilized in Hua, which is $34.4 \mathrm{~m}^{2} / \mathrm{g}$. The reason for this is due to the special microstructure of bentonite, which consists of irregular groups that have an average diameter of approximately 0.1 to $10 \mu \mathrm{m}$ [42]. These groups are composed of a certain number of particles whose lateral dimensions range from 8 to $10 \mathrm{~nm}$. At the same time, these particles are made up of 5 to 10 layers, whose dimensions are 100 to $200 \mathrm{~nm}$ in diameter and only $1 \mathrm{~nm}$ in thickness [43]. Additionally, the average pore size of fly ash is $114.2 \AA$. The total pore volume and micropore volume of the fly ash are $2.710 \times 10^{-2} \mathrm{~mL} / \mathrm{g}$ and $2.516 \times 10^{-2} \mathrm{~mL} / \mathrm{g}$, respectively.

$\mathrm{XRF}$ results of untreated fly ash and OPC are displayed in Table 3. Based on the XRD pattern shown in Figure 5, untreated fly ash is composed of calcite $\left(\mathrm{CaCO}_{3}\right)$ and calcium chlorite hydrate $\left(\mathrm{Ca}(\mathrm{ClO})_{2} \cdot 4 \mathrm{H}_{2} \mathrm{O}\right)$, which are

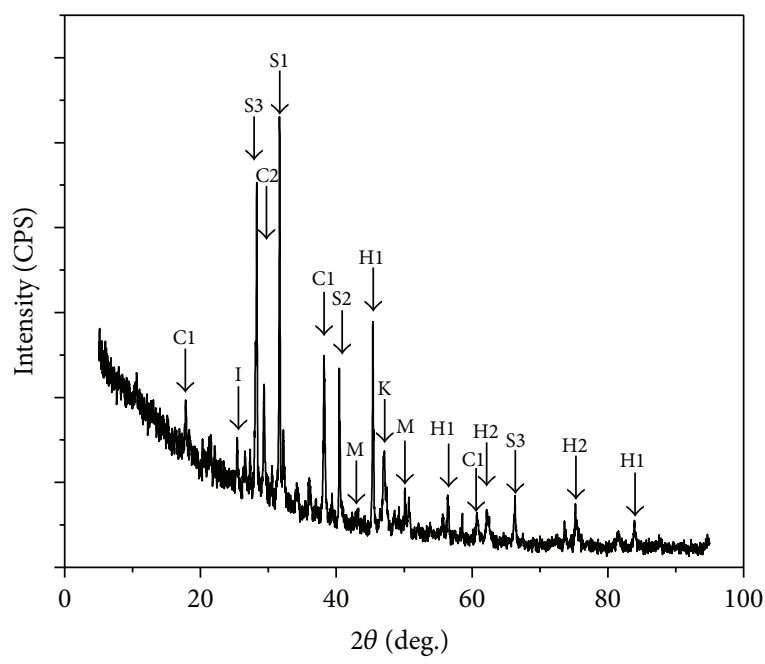

$\begin{array}{ll}\text { C1: calcium chlorite hydrate } & \text { K: kyanite } \\ \text { C2: calcite } & \text { M: maghemite } \\ \text { H1: halite } & \text { S1: silicon chloride } \\ \text { H2: hematite } & \text { S2: silicon titanium } \\ \text { I: iron manganese titanium oxide } & \text { S3: sylvite }\end{array}$

FIGURE 5: XRD pattern of fly ash.

observed at $2 \theta=29.36^{\circ}$ and $\left(17.80^{\circ}, 38.20^{\circ}, 60.73^{\circ}\right)$. XRF results corroborate the presence of these two substances and $\mathrm{CaO}$ accounts for $41.80 \%$ of the total contents. According to Anastasiadou et al.'s study, the calcite was also observed [1]. From Table 3, fly ash contains $11.53 \% \mathrm{SiO}_{2}, 10.89 \% \mathrm{Cl}$, and $5.71 \% \mathrm{Al}_{2} \mathrm{O}_{3}$. The presences of kyanite $\left(\mathrm{Al}_{2} \mathrm{O}_{3} \cdot \mathrm{SiO}_{2}\right)$ and silicon chlorite $\left(\mathrm{SiCl}_{4}\right)$ are verified at $2 \theta=47.09^{\circ}$ and $31.64^{\circ}$ as well. Faleschini et al. also demonstrated that kyanite exists in fly ash [44]. Considering the existence of $\mathrm{Na}_{2} \mathrm{O}$ and $\mathrm{K}_{2} \mathrm{O}$ shown by XRF results, the characteristic peaks at $2 \theta=\left(45.38^{\circ}\right.$, $\left.56.41^{\circ}, 83.92^{\circ}\right)$ and $\left(28.30^{\circ}, 66.34^{\circ}\right)$ shown in the XRD pattern indicate the presence of halite $(\mathrm{NaCl})$ and sylvite $(\mathrm{KCl})$. This also agrees with Liu et al's study [45]. In addition, hematite $\left(\mathrm{Fe}_{2} \mathrm{O}_{3}\right)$, maghemite $\left(\mathrm{Fe}_{3} \mathrm{O}_{4}\right)$, iron manganese titanium oxide $\left(\mathrm{Fe}_{2} \mathrm{MnTi}_{3} \mathrm{O}_{10}\right)$, and silicon titanium $\left(\mathrm{TiSi}_{2}\right)$ appearing at $2 \theta$ $=\left(62.14^{\circ}, 75.22^{\circ}\right),\left(43.27^{\circ}, 50.14^{\circ}\right), 25.42^{\circ}$, and $40.45^{\circ}$ are in accordance with XRF analysis, in which $2.57 \% \mathrm{Fe}_{2} \mathrm{O}_{3}, 0.68 \%$ $\mathrm{Ti}_{2} \mathrm{O}$, and $0.07 \% \mathrm{MnO}$ are detected.

3.2. Compressive Strength Test Results. The compressive strength values of the cement-based fly ash mixtures under different curing periods are presented in Figure 6. At cement/fly ash ratios of $4: 6,5: 5,6: 4,7: 3$, and $8: 2$, the compressive strengths are $0.45-1.53 \mathrm{MPa}, 0.63-2.57 \mathrm{MPa}, 0.49-$ $2.52 \mathrm{MPa}, 0.60-2.59 \mathrm{MPa}$, and $0.75-2.67 \mathrm{MPa}$, respectively. Compared to 3 days of curing, the compressive strength of mixtures with 28 days of curing time increases by $157.8 \%$ (4:6), $84.1 \%$ (5:5), $179.6 \%(6: 4), 175.0 \%(7: 3)$, and $120.0 \%$ $(8: 2)$, respectively. These results were in good agreement with the Anastasiadou et al.s study, where the compressive strength of mixtures increased by $200.0 \%(4: 6), 700.0 \%$ $(5: 5)$, and $404.0 \%(6: 4)$ by comparing the values after 28 days of curing with 1 day of curing [1]. All values of compressive strength for the test mixtures exceed the standard (ASTM 

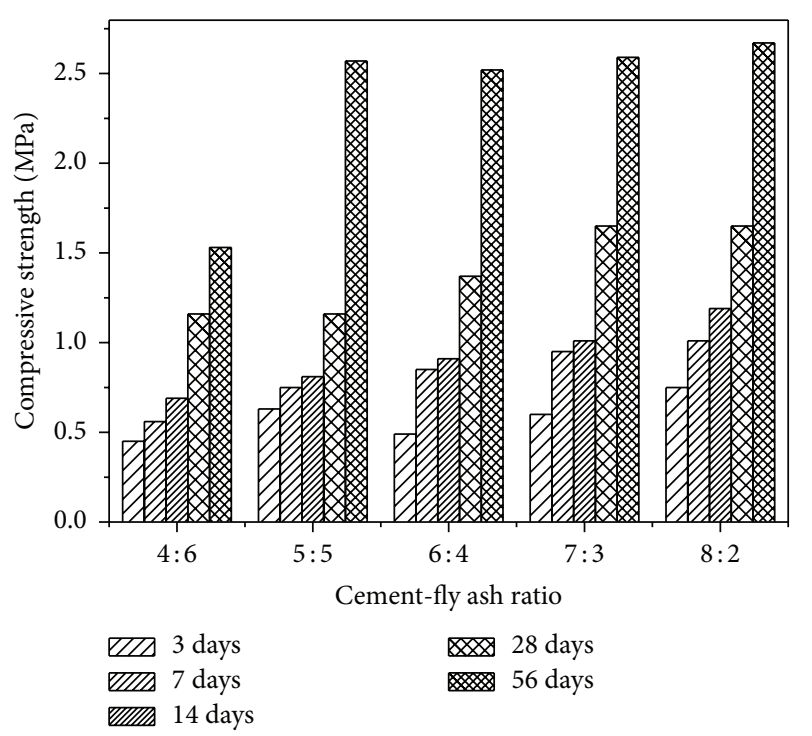

FIGURE 6: Compressive strength of cemented solidified fly ash.

STP 1123) stipulated for solidified waste to be landfilled, which is $0.414 \mathrm{MPa}[1,7]$.

Figure 6 shows that the compressive strength of mixtures increases with the curing time. This is because the hydration reaction will be more complete when the curing time is longer. Two processes are involved during the period of cement hydration reaction. One is through-solution hydration, which involves several factors including dissolution of anhydrous compounds into their ionic constituents, formation of hydrates in the solution, and eventual precipitation of hydrates from the supersaturated solution. The other is solid-state hydration of cement and the reactions occurring directly at the surface of the anhydrous cement compounds. During this period, no compounds dissolve into solution. In the early stage of cement hydration, through-solution hydration is dominant. At the poststage of cement hydration, the hydration of residual cement particles may occur by the solid-state reactions and the migration of ions in the solution becomes restricted [46].

For cement/fly ash ratio, the attributes of the mixture will be closer to the pure OPC when cement/fly ash ratio is larger. Therefore, the compressive strength decreases as the cement/fly ash ratio is reduced. This phenomenon can be analyzed from four aspects, specifically, the formation of ettringite (AFt), the structure of products of hydration, pozzolanic reaction, and the fixation of water molecules. Firstly, when the addition of fly ash increases, the formation of AFt, which supports the development of the early strength, will be reduced [47]. Due to the presence of fly ash, a part of the aluminate, which should participate in the formation of $\mathrm{AFt}$, is seized to form Friedel's salt. It is inferred that the more the fly ash that is added, the more the aluminate that reacts to form Friedel's salt and the larger the decrease in magnitude of strength. Regarding the AFt, a more concrete discussion will be given in Section 3.3.

Secondly, the residues in fly ash that are not completely burnt also influence the compressive strength of the solidified matrix. The products of cement hydration are lapped and bound by the multiple gravitation. This is the reason why cement blocks have a high compressive strength. However, the high levels of residues in fly ash not only reduce the concentration of products from cement hydration, which have connection effect, but also destroy the structure of products of hydration [48]. This also explains the phenomenon that the compressive strength of mixtures decreases with the increase of fly ash loading.

Thirdly, when fly ash is added to OPC, it will undergo the pozzolanic reaction. Due to similar chemical composition, fly ash can be classified as a pozzolan, which is one of two main components used in production of concrete. The other is cement [26]. When added to OPC, fly ash, as a pozzolan, undergoes the pozzolanic reaction with calcium hydroxide, which is slow, and the rate of strength development will accordingly slow down. Regarding the hydration reaction, a comparison between Portland cement and Portlandpozzolan cement is given as follows.

Portland cement:

$$
\mathrm{C}_{3} \mathrm{~S}+\mathrm{H} \stackrel{\text { fast }}{\longrightarrow} \mathrm{C}-\mathrm{S}-\mathrm{H}+\mathrm{CH}
$$

Portland-pozzolan cement:

$$
\text { Pozzolan }+\mathrm{CH}+\mathrm{H} \stackrel{\text { slow }}{\longrightarrow} \mathrm{C}-\mathrm{S}-\mathrm{H}
$$

where $\mathrm{C}, \mathrm{S}$, and $\mathrm{H}$ represents $\mathrm{CaO}, \mathrm{SiO}_{2}$, and $\mathrm{H}_{2} \mathrm{O}$, respectively [46]. When the cement/fly ash ratio is low, the hydration of Portland-pozzolan cement has the higher tendency to take place following (2). This is another reason for the decrease of compressive strength associated with the decrease of cement/fly ash ratio.

Fourthly, fly ash will bind water, which should participate in the hydration of cement, due to its strong ability to fix water molecules. Based on the work by Mitchell and Soga, the surface charges of fly ash particles, along with hydrogen bonds on the particle surface and van Der Waals forces between water molecules and fly ash particles, contribute to the fixation of water molecules [49]. As shown in Table 2, the specific surface area of fly ash is $7.944 \mathrm{~m}^{2} / \mathrm{g}$, which provides a favorable condition for attracting water, considering the interaction between water and fly ash particles. That is expected by the results of the preliminary tests in Section 2.2. For the samples with various initial moisture contents, 7.22\%$53.00 \%$ water reacted with fly ash. The ability to strongly fix water molecules is also corroborated by the water retention capacity displayed in Table 2. When the water is bound by fly ash, the hydration reaction is incomplete. This is why fly ash loading leads to a decrease of compressive strength. Obviously, the more fly ash is added, the more water is attracted. Thereby, the compressive strength of fly ash mixtures decreases accordingly.

3.3. Leaching Test Results. The TCLP leaching amounts of fly ash samples after 3,7, 14, 28, and 56 days of curing are displayed in Table 4. For treated fly ash, the final leaching amount of all measured metals is lower than the US EPA standard (40 CFR 261.24) [8]. Compared to the untreated 
TABLE 4: Summary of TCLP leaching results for solidified fly ash samples.

\begin{tabular}{|c|c|c|c|c|c|c|c|}
\hline \multirow{2}{*}{ Cement/fly ash } & \multirow{2}{*}{ Curing time } & \multicolumn{6}{|c|}{ Concentration of metals in leachate $(\mathrm{mg} / \mathrm{L})$} \\
\hline & & $\mathrm{Cr}$ & $\mathrm{Cd}$ & $\mathrm{Pb}$ & $\mathrm{Ni}$ & $\mathrm{Cu}$ & $\mathrm{Mn}$ \\
\hline Untreated fly ash & & 0.85 & 6.40 & 15.50 & 1.04 & 0.19 & - \\
\hline 40 CFR 261.24 & & 5 & 1 & 5 & 100 & 100 & - \\
\hline \multirow{5}{*}{$8: 2$} & $3 d$ & 0.722 & 0.084 & 0.821 & 0.188 & 0.115 & 0.113 \\
\hline & $7 \mathrm{~d}$ & 0.601 & 0.076 & 0.688 & 0.182 & 0.092 & 0.094 \\
\hline & $14 \mathrm{~d}$ & 0.541 & 0.073 & 0.465 & 0.176 & 0.084 & 0.040 \\
\hline & $28 \mathrm{~d}$ & 0.433 & 0.056 & 0.255 & 0.169 & 0.009 & 0.034 \\
\hline & $56 \mathrm{~d}$ & 0.455 & 0.057 & 0.236 & 0.157 & 0.013 & 0.045 \\
\hline \multirow{5}{*}{$7: 3$} & $3 \mathrm{~d}$ & 0.843 & 0.148 & 0.907 & 0.200 & 0.189 & 0.194 \\
\hline & $7 \mathrm{~d}$ & 0.547 & 0.106 & 0.741 & 0.190 & 0.167 & 0.145 \\
\hline & $14 \mathrm{~d}$ & 0.472 & 0.069 & 0.669 & 0.156 & 0.109 & 0.037 \\
\hline & $28 \mathrm{~d}$ & 0.361 & 0.044 & 0.321 & 0.140 & 0.099 & 0.034 \\
\hline & $56 \mathrm{~d}$ & 0.367 & 0.048 & 0.189 & 0.138 & 0.098 & 0.014 \\
\hline \multirow{5}{*}{$6: 4$} & $3 \mathrm{~d}$ & 0.823 & 0.094 & 1.014 & 0.218 & 0.131 & 0.157 \\
\hline & $7 \mathrm{~d}$ & 0.746 & 0.092 & 0.547 & 0.207 & 0.112 & 0.148 \\
\hline & $14 \mathrm{~d}$ & 0.486 & 0.073 & 0.493 & 0.198 & 0.092 & 0.116 \\
\hline & $28 \mathrm{~d}$ & 0.450 & 0.045 & 0.448 & 0.176 & 0.087 & 0.097 \\
\hline & $56 \mathrm{~d}$ & 0.530 & 0.057 & 0.494 & 0.188 & 0.097 & 0.078 \\
\hline \multirow{5}{*}{$5: 5$} & $3 \mathrm{~d}$ & 0.798 & 0.106 & 0.893 & 0.245 & 0.173 & 0.152 \\
\hline & $7 \mathrm{~d}$ & 0.493 & 0.088 & 0.684 & 0.236 & 0.096 & 0.132 \\
\hline & $14 \mathrm{~d}$ & 0.444 & 0.066 & 0.220 & 0.225 & 0.079 & 0.046 \\
\hline & $28 \mathrm{~d}$ & 0.423 & 0.048 & 0.142 & 0.214 & 0.045 & 0.021 \\
\hline & $56 \mathrm{~d}$ & 0.480 & 0.069 & 0.238 & 0.205 & 0.034 & 0.013 \\
\hline \multirow{5}{*}{$4: 6$} & $3 \mathrm{~d}$ & 0.828 & 0.104 & 0.944 & 0.241 & 0.123 & 0.147 \\
\hline & $7 \mathrm{~d}$ & 0.601 & 0.092 & 0.644 & 0.221 & 0.098 & 0.129 \\
\hline & $14 \mathrm{~d}$ & 0.490 & 0.080 & 0.480 & 0.213 & 0.086 & 0.071 \\
\hline & $28 \mathrm{~d}$ & 0.357 & 0.070 & 0.390 & 0.215 & 0.062 & 0.031 \\
\hline & $56 \mathrm{~d}$ & 0.341 & 0.067 & 0.342 & 0.213 & 0.088 & 0.033 \\
\hline
\end{tabular}

Note: “-" = not available.

fly ash from Table 4, the leaching amounts of heavy metals after 3 days of curing decrease by approximately $98.33 \%$ $(\mathrm{Cd}), 94.09 \%(\mathrm{~Pb})$, and $79.00 \%(\mathrm{Ni})$. The decreases of the leaching amounts of $\mathrm{Cr}$ and $\mathrm{Cu}$ are $0.82 \%-15.06 \%$ and $0.53 \%-$ $39.47 \%$, respectively. After 56 days of curing, the decreases of the leaching amounts of heavy metals are approximately 98.91\% (Cd), 98.52\% (Pb), 82.17\% (Ni), 37.65\%-59.88\% (Cr), and $48.42 \%-93.16 \%(\mathrm{Cu})$. The leaching amount of all heavy metals decreases with the increase of curing time. This finding is also proved by Anastasiadou et al. [1]. In Anastasiadou et al's research, comparing the samples after 1 day of curing, the leaching-out heavy metal amount from samples after 28 days decreases by a wide margin. For example, $\mathrm{Cr}, \mathrm{Ni}$, $\mathrm{Cu}, \mathrm{Cd}$, and $\mathrm{Pb}$ decrease by $28.9 \%, 30.6 \%, 30.6 \%, 57.1 \%$, and $64.5 \%$ [1]. According to Table 4, however, the leaching amounts of some heavy metals such as $\operatorname{Cr}(5: 5,6: 4)$ and $\mathrm{Cu}(4: 6,6: 4$, and $8: 2)$ after 56 days of curing are higher than those after 28 days of curing. It indicates that a part of heavy metals have released from the material again after 28 days of curing, and two reasons can be concluded as given below. First of all, as mentioned in Section 2.2, the humidity during the curing process is relatively high $(\geq 95 \%)$. Therefore, the carbon dioxide in the air tends to dissolve in water and forms carbonic acid, resulting in the decrease of alkalinity. According to Beaudoin and Brown, C-S-H gel is unstable when $\mathrm{pH}$ is lower than 10.0 [50]. Thus, it is rational to judge that the barriers provided by C-S-H, especially covered at the outward surface, have the tendency to be destroyed due to the decrease in alkalinity as the curing period increased and caused the release of fixed heavy metals. In addition, carbonic acid also redissolves heavy metal ion precipitates, making heavy metals exist in free ion form. Table 4 also shows that the leaching amount of $\mathrm{Cr}$ is much higher than that of $\mathrm{Cu}(\mathrm{II})$. According to the results calculated by Visual MINTEQ as shown in Table 5, that may be attributed to the soluble form of $\mathrm{Cr}(\mathrm{VI})$ in the alkaline environment. Table 5 shows that $100 \%$ $\mathrm{Cr}$ exists in the form of soluble ions $\left(\mathrm{CrO}_{4}{ }^{2-}\right.$ or $\left.\mathrm{HCrO}_{4}{ }^{-}\right)$ when $\mathrm{pH}$ ranges from 10.0 to 12.0 , while $0.466 \%-11.594 \% \mathrm{Cu}$ exists as the precipitate $\left(\mathrm{Cu}(\mathrm{OH})_{2}\right)$. The similar phenomenon is also observed by Mulligan et al., in which $\mathrm{Cr}(\mathrm{VI})$ is found hard to transform into a low soluble hydroxide [51].

The mechanisms of $\mathrm{S} / \mathrm{S}$ can be generally divided into two processes: physical encapsulation and chemical immobilization. The former provides barriers generated on the surface 
TABLE 5: The percentage of possible ion forms of $\mathrm{Cu}(\mathrm{II})$ and $\mathrm{Cr}(\mathrm{VI})$.

\begin{tabular}{|c|c|c|c|c|c|c|c|}
\hline & \multirow{2}{*}{$\mathrm{pH}$} & \multicolumn{6}{|c|}{ Percentage of possible ion forms (\%) } \\
\hline & & A & B & C & $\mathrm{D}$ & E & $\mathrm{F}$ \\
\hline \multirow{6}{*}{$\mathrm{Cr}(\mathrm{VI})$} & \multirow[t]{2}{*}{10.0} & $\mathrm{CrO}_{4}{ }^{2-}$ & $\mathrm{HCrO}_{4}{ }^{-}$ & - & - & - & - \\
\hline & & 99.987 & 0.013 & - & - & - & - \\
\hline & \multirow[t]{2}{*}{11.0} & $\mathrm{CrO}_{4}{ }^{2-}$ & - & - & - & - & - \\
\hline & & 99.999 & - & - & - & - & - \\
\hline & \multirow[t]{2}{*}{12.0} & $\mathrm{CrO}_{4}{ }^{2-}$ & - & - & - & - & - \\
\hline & & 100 & - & - & - & - & - \\
\hline \multirow{6}{*}{$\mathrm{Cu}(\mathrm{II})$} & \multirow[t]{2}{*}{10.0} & $\mathrm{CuOH}^{+}$ & $\mathrm{Cu}(\mathrm{OH})_{3}{ }^{-}$ & $\mathrm{Cu}(\mathrm{OH})_{2}$ & $\mathrm{Cu}_{2}(\mathrm{OH})_{2}{ }^{2+}$ & $\mathrm{Cu}_{3}(\mathrm{OH})_{4}{ }^{2+}$ & - \\
\hline & & 0.036 & 0.262 & 0.466 & 0.155 & 99.081 & - \\
\hline & \multirow[t]{2}{*}{11.0} & $\mathrm{CuOH}^{+}$ & $\mathrm{Cu}(\mathrm{OH})_{4}{ }^{2-}$ & $\mathrm{Cu}(\mathrm{OH})_{3}{ }^{-}$ & $\mathrm{Cu}(\mathrm{OH})_{2}$ & $\mathrm{Cu}_{2}(\mathrm{OH})_{2}{ }^{2+}$ & $\mathrm{Cu}_{3}(\mathrm{OH})_{4}{ }^{2+}$ \\
\hline & & 0.016 & 0.236 & 11.594 & 2.065 & 0.030 & 86.059 \\
\hline & \multirow[t]{2}{*}{12.0} & $\mathrm{Cu}(\mathrm{OH})_{4}{ }^{2-}$ & $\mathrm{Cu}(\mathrm{OH})_{3}{ }^{-}$ & $\mathrm{Cu}(\mathrm{OH})_{2}$ & $\mathrm{Cu}_{3}(\mathrm{OH})_{4}{ }^{2+}$ & - & - \\
\hline & & 16.717 & 81.539 & 1.443 & 0.300 & - & - \\
\hline
\end{tabular}

of the waste to restrict contaminant migration by mechanical processes or chemical reactions. The latter refers to the processes that keep heavy metals in a certain form by chemical reactions to reduce the leachability. The related mechanisms are also validated by Sobiecka et al. [26]. The importance of fly ash solidification/stabilization can be specifically expounded using the following three aspects. Firstly, the migration of heavy metal ions is hindered by the products of the cement hydration reactions. The solidification processes result in the formation of C-S-H gel on the surface of the stabilized fly ash particles. C-S-H gel acts as a barrier between the immobilized solid wastes and the surrounding liquids and controls the potential adsorption of ions present in the liquids onto the surface of the solid waste, as well as the immobilization of heavy metals in the resulting products [52]. Based on the aforementioned theory, it can be inferred that the hydration reaction of OPC is more sufficient and the amount of C-S-H gel is larger by prolonging the curing time. That can explain why the leaching amount of heavy metals decreases with the increase of curing time.

Secondly, heavy metal ions are absorbed by the products of the cement hydration reaction. The absorption can be divided into the physical absorption and chemical absorption. Physical absorption is caused by van Der Waals forces between particles, while chemical absorption is the result of chemical bond formation [53]. Due to the porous structure and small crystal particles, the specific surface area of cement hydration reaction products ranges from 10 to $50 \mathrm{~m}^{2} / \mathrm{g}$ [54]. This creates a favorable condition for physical absorption. As mentioned before, with the increase in cement/fly ash ratio, the products of cement hydration reaction also increase, and the effect of physical absorption will therefore be more remarkable. This is corroborated in Table 4, which demonstrates that the highest leaching levels of heavy metals occur at the smallest cement/fly ash ratio $(4: 6)$. However, according to Liu et al., $\mathrm{Cr}$ cannot be effectively removed through the physical absorption when $\mathrm{pH}$ is over 10.0 [55]. Given the alkaline environment during the cement hydration reaction, this can help explain why the immobilization of $\mathrm{Cr}$ is not very efficient.
Thirdly, the $\mathrm{Ca}(\mathrm{II})$ in the structure of AFt can be replaced by divalent heavy metal ions, including $\mathrm{Zn}$ (II), Cd(II), $\mathrm{Pb}$ (II), and $\mathrm{Ni}(\mathrm{II})$, through isomorphous replacement. Similarly, the $\mathrm{Al}(\mathrm{III})$ can be replaced by trivalent or tetravalent heavy metal ions, including $\mathrm{Cr}$ (III), $\mathrm{Mn}$ (III), Ti(III), and $\mathrm{Ti}(\mathrm{IV})$ [54]. These reactions have a certain relationship with the ionic radius. For instance, the ionic radii of some divalent heavy metal ions are $0.074 \mathrm{~nm}(\mathrm{Zn}(\mathrm{II})), 0.095 \mathrm{~nm}(\mathrm{Cd}(\mathrm{II}))$, and $0.069 \mathrm{~nm}(\mathrm{Ni}(\mathrm{II}))$, which are relatively smaller and denser than that of $\mathrm{Ca}$ (II) $(0.1 \mathrm{~nm})$. Therefore, these heavy metal ions have the tendency to replace $\mathrm{Ca}$ (II) in the AFt due to the stronger attractive force. However, with an increase in fly ash loading, the formation of AFt will be hindered. The calcium sulfate and chloride in fly ash can influence the hydration of cement at the same time. On the one hand, the calcium sulfate in fly ash tends to react with aluminate in cement to generate AFt. The chemical reaction can be expressed as follows:

$$
\begin{aligned}
& {\left[\mathrm{Al}(\mathrm{OH})_{4}\right]^{-}+3\left[\mathrm{SO}_{4}\right]^{2-}+6[\mathrm{Ca}]^{2+}+\text { aq. }} \\
& \quad \longrightarrow \mathrm{C}_{6} \mathrm{AS}_{3} \mathrm{H}_{32}
\end{aligned}
$$

where $\mathrm{C}, \mathrm{A}, \overline{\mathrm{S}}$, and $\mathrm{H}$ represent $\mathrm{CaO}, \mathrm{Al}_{2} \mathrm{O}_{3}, \mathrm{SO}_{3}$, and $\mathrm{H}_{2} \mathrm{O}$. On the other hand, the large amount of chloride in fly ash dissolves into the solution existing in the pores of cement and tends to form calcium chloride, which can react with aluminate in cement and generate Friedel's salt. The impacts on the hydration reaction of aluminate are the opposite, resulting in a competition between the two reactions. As a matter of fact, compared with the pure cement paste, only a small amount of aluminate may react with sulfate. This indicates that the latter reaction is dominant in the process [44]. Therefore, the addition of fly ash reduces the formation of AFt. This explains why the maximum leaching amount of heavy metal ion occurs at the minimum cement/fly ash ratio $(4: 6)$.

\section{Conclusions}

In this study, compressive strength test and TCLP test were conducted on the cement-stabilized fly ash. The mechanical 
behavior of the fly ash mixtures and the leaching behaviors of heavy metal ions $(\mathrm{Cr}, \mathrm{Cd}, \mathrm{Pb}, \mathrm{Ni}, \mathrm{Cu}$, and $\mathrm{Mn}$ ) were investigated. According to the compressive strength test results, the compressive strength of the mixtures grew with the increase of cement/fly ash ratio and curing time. For the TCLP test results, it was shown that the leaching amounts of heavy metals decreased with the increase of cement/fly ash ratio and curing time. After the cement $S / S$ treatment, the final leaching amounts of heavy metals were effectively controlled, which is lower than the US EPA standard. Combined with the XRF and XRD analysis, it was found that the formation of AFt was hindered due to the presence of fly ash and thereby reduced the compressive strength and blocked the immobilization of heavy metals. In addition, fly ash loading destroyed the structure of the products of cement hydration. This resulted in the pozzolanic reaction and fixation of water molecules, which further increased the compressive strength of test samples. The formation of C-S-H gel, along with the adsorption of products, restricted the migration of ions and ultimately reduced the total amount of leachate.

\section{Competing Interests}

The authors declare that they have no competing interests.

\section{Acknowledgments}

The research presented herein is supported by the National Nature Science Foundation of China (Grant no. 41630633), China Postdoctoral Science Foundation funded project (Grant no. 2016M591756), and the Open Project Program of MOE Key Laboratory of Soft Soils and Geoenvironmental Engineering, Zhejiang University (Grant no. 2016P03). The research is also supported by Jiangsu Provincial Transport Bureau, Bureau of Housing and Urban-Rural Development of Suzhou, and Soft Science Research Program from Suzhou Association for Science and Technology.

\section{References}

[1] K. Anastasiadou, K. Christopoulos, E. Mousios, and E. Gidarakos, "Solidification/stabilization of fly and bottom ash from medical waste incineration facility," Journal of Hazardous Materials, vol. 207-208, no. 6, pp. 165-170, 2012.

[2] Y. L. Galiano, C. F. Pereira, and J. Vale, "Stabilization/solidification of a municipal solid waste incineration residue using fly ash-based geopolymers," Journal of Hazardous Materials, vol. 185, no. 1, pp. 373-381, 2011.

[3] European Commission, Eurostat Yearbook 2011, Eurostat, 2011.

[4] H.-U. Hartenstein and M. Horvay, "Overview of municipal waste incineration industry in west Europe (based on the German experience)," Journal of Hazardous Materials, vol. 47, no. 1-3, pp. 19-30, 1996.

[5] "Waste treatment in Japan," Ministry of Environment, Waste Management and Recycling Unit, 2011 (Japanese).

[6] Q. Tang, X. Tang, M. Hu, Z. Li, Y. Chen, and P. Lou, "Removal of Cd(II) from aqueous solution with activated Firmiana Simplex Leaf: behaviors and affecting factors," Journal of Hazardous Materials, vol. 179, no. 1-3, pp. 95-103, 2010.
[7] American Society for Testing and Materials, "Stabilization and solidification of hazardous, radioactive, and mixed wastes," ASTM STP 1123, 1992.

[8] US Environmental Protection Agency, Definition of Solid Waste and Hazardous Waste Recycling, 2001.

[9] M. Ahmaruzzaman, "A review on the utilization of fly ash," Progress in Energy and Combustion Science, vol. 36, no. 3, pp. 327-363, 2010.

[10] L. Reijnders, "Disposal, uses and treatments of combustion ashes: a review," Resources, Conservation and Recycling, vol. 43, no. 3, pp. 313-336, 2005.

[11] W.-H. Choi, S.-R. Lee, and J.-Y. Park, "Cement based solidification/stabilization of arsenic-contaminated mine tailings," Waste Management, vol. 29, no. 5, pp. 1766-1771, 2009.

[12] F. Y. Song, L. Gu, N. W. Zhu, and H. P. Yuan, "Leaching behavior of heavy metals from sewage sludge solidified by cement-based binders," Chemosphere, vol. 92, no. 4, pp. 344-350, 2013.

[13] I. G. Richardson and G. W. Groves, "The incorporation of minor and trace elements into calcium silicate hydrate $(\mathrm{C}-\mathrm{S}-\mathrm{H})$ gel in hardened cement pastes," Cement and Concrete Research, vol. 23, no. 1, pp. 131-138, 1993.

[14] F. Ziegler, A. M. Scheidegger, C. A. Johnson, R. Dáhn, and E. Wieland, "Sorption mechanisms of zinc to calcium silicate hydrate: X-ray absorption fine structure (XAFS) investigation," Environmental Science and Technology, vol. 35, no. 7, pp. 15501555, 2001.

[15] G. E. Voglar and D. Leštan, "Solidification/stabilisation of metals contaminated industrial soil from former $\mathrm{Zn}$ smelter in Celje, Slovenia, using cement as a hydraulic binder," Journal of Hazardous Materials, vol. 178, no. 1-3, pp. 926-933, 2010.

[16] H. Patel and S. Pandey, "Evaluation of physical stability and leachability of Portland Pozzolona Cement (PPC) solidified chemical sludge generated from textile wastewater treatment plants," Journal of Hazardous Materials, vol. 207-208, pp. 56-64, 2012.

[17] ISBN, 2nd edition.

[18] Ministry of Housing and Urban-Rural Development of the People's Republic of China, Standard for Soil Test Method, 1999.

[19] American Society for Testing and Materials, "Standard test method for swell index of clay mineral component of geosynthetic clay liners," ASTM D5890-06, ASTM International, West Conshohocken, Pa, USA, 2006.

[20] European Union, Heavy Metals in Wastes, European Commission on Environment, 2009.

[21] Canadian Environmental Council of Ministers of the Environment, Soil Quality Guidelines for the Protection of Environmental and Human Health, 1999.

[22] Ministry of Environmental Protection of the People's Republic of China, Environmental Quality Standards for Soils, 2009.

[23] J. Yu, Y. Qiao, L. Jin, C. Ma, N. Paterson, and L. Sun, "Removal of toxic and alkali/alkaline earth metals during co-thermal treatment of two types of MSWI fly ashes in China," Waste Management, vol. 46, pp. 287-297, 2015.

[24] Y. Y. Hu, P. F. Zhang, J. P. Li, and D. Z. Chen, "Stabilization and separation of heavy metals in incineration fly ash during the hydrothermal treatment process," Journal of Hazardous Materials, vol. 299, pp. 149-157, 2015.

[25] F.-H. Wang, F. Zhang, Y.-J. Chen, J. Gao, and B. Zhao, "A comparative study on the heavy metal solidification/stabilization performance of four chemical solidifying agents in municipal solid waste incineration fly ash," Journal of Hazardous Materials, vol. 300, pp. 451-458, 2015. 
[26] E. Sobiecka, A. Obraniak, and B. Antizar-Ladislao, "Influence of mixture ratio and $\mathrm{pH}$ to solidification/stabilization process of hospital solid waste incineration ash in Portland cement," Chemosphere, vol. 111, pp. 18-23, 2014.

[27] M. Kamon, T. Katsumi, and Y. Sano, "MSW fly ash stabilized with coal ash for geotechnical application," Journal of Hazardous Materials, vol. 76, no. 2-3, pp. 265-283, 2000.

[28] A. T. Lima, L. M. Ottosen, and A. B. Ribeiro, "Assessing fly ash treatment: remediation and stabilization of heavy metals," Journal of Environmental Management, vol. 95, pp. S110-S115, 2012.

[29] F. Lombardi, T. Mangialardi, L. Piga, and P. Sirini, "Mechanical and leaching properties of cement solidified hospital solid waste incinerator fly ash," Waste Management, vol. 18, no. 2, pp. 99106, 1998.

[30] G. M. Kirkelund, C. Magro, P. Guedes, P. E. Jensen, A. B. Ribeiro, and L. M. Ottosen, "Electrodialytic removal of heavy metals and chloride from municipal solid waste incineration fly ash and air pollution control residue in suspension-test of a new two compartment experimental cell," Electrochimica Acta, vol. 181, pp. 73-81, 2015.

[31] B. Nowak, P. Aschenbrenner, and F. Winter, "Heavy metal removal from sewage sludge ash and municipal solid waste fly ash-a comparison," Fuel Processing Technology, vol. 105, pp. 195-201, 2013.

[32] S. Sushil and V. S. Batra, "Analysis of fly ash heavy metal content and disposal in three thermal power plants in India," Fuel, vol. 85, no. 17-18, pp. 2676-2679, 2006.

[33] B. Van Der Bruggen, G. Vogels, P. Van Herck, and C. Vandecasteele, "Simulation of acid washing of municipal solid waste incineration fly ashes in order to remove heavy metals," Journal of Hazardous Materials, vol. 57, no. 1-3, pp. 127-144, 1998.

[34] F. Gu, Y. Zhang, C. V. Droddy, R. Luo, and R. L. Lytton, "Development of a new mechanistic empirical rutting model for unbound granular material," Journal of Materials in Civil Engineering, vol. 28, no. 8, Article ID 4016051, 2016.

[35] F. Gu, H. Sahin, X. Luo, R. Luo, and R. L. Lytton, "Estimation of resilient modulus of unbound aggregates using performancerelated base course properties," Journal of Materials in Civil Engineering, vol. 27, no. 6, Article ID 04014188, 2015.

[36] U.S. Environmental Protection Agency, "Toxicity characteristic leaching procedure," US EPA Test Method 1311, 1984.

[37] T. D. Tran, Y.-J. Cui, A. M. Tang, M. Audiguier, and R. Cojean, "Effects of lime treatment on the microstructure and hydraulic conductivity of Héricourt clay," Journal of Rock Mechanics and Geotechnical Engineering, vol. 6, no. 5, pp. 399-404, 2014.

[38] Q. Tang, T. Katsumi, T. Inui, and Z. Li, "Membrane behavior of bentonite-amended compacted clay," Soils and Foundations, vol. 54, no. 3, pp. 329-344, 2014.

[39] T. Qiang, K. Heejong, E. Kazuto, K. Takeshi, and I. Toru, "Size effect on lysimeter test evaluating the properties of construction and demolition waste leachate," Soils and Foundations, vol. 55, no. 4, pp. 720-736, 2015.

[40] M. Taghipour and M. Jalali, "Effect of clay minerals and nanoparticles on chromium fractionation in soil contaminated with leather factory waste," Journal of Hazardous Materials, vol. 297, pp. 127-133, 2015.

[41] M. Ghrici, S. Kenai, and M. Said-Mansour, "Mechanical properties and durability of mortar and concrete containing natural pozzolana and limestone blended cements," Cement and Concrete Composites, vol. 29, no. 7, pp. 542-549, 2007.
[42] J. Hua, "Synthesis and characterization of bentonite based inorgano-organo-composites and their performances for removing arsenic from water," Applied Clay Science, vol. 114, pp. 239-246, 2015.

[43] H. Han and Y. Zhu, "Study on modification and application of bentonite," Inorganic Chemicals Industry, vol. 43, pp. 5-8, 2011 (Chinese).

[44] F. Faleschini, M. A. Zanini, K. Brunelli, and C. Pellegrino, "Valorization of co-combustion fly ash in concrete production," Materials and Design, vol. 85, pp. 687-694, 2015.

[45] Y. Q. Liu, W. P. Zhu, and E. H. Yang, "Alkali-activated ground granulated blast-furnace slag incorporating incinerator fly ash as a potential binder," Construction and Building Materials, vol. 112, pp. 1005-1012, 2016.

[46] P. K. Mehta and P. J. M. Monteiro, Concrete: Microstructure, Properties, and Materials, McGraw-Hill Education, 4th edition, 2014.

[47] S. Rémond, D. P. Bentz, and P. Pimienta, "Effects of the incorporation of municipal solid waste incineration fly ash in cement pastes and mortars: II: modeling," Cement and Concrete Research, vol. 32, no. 4, pp. 565-576, 2002.

[48] H.-Q. Liu, G.-X. Wei, S.-G. Zhang, and J.-J. Cai, "Effect of activated carbon on cement solidification of hospital waste incineration fly ash," The Chinese Journal of Process Engineering, vol. 8, no. 5, pp. 953-956, 2008 (Chinese).

[49] J. K. Mitchell and K. Soga, Fundamentals of Soil Behavior, John Wiley \& Sons, New York, NY, USA, 3rd edition, 2005.

[50] J. J. Beaudoin and P. W. Brown, "The structure of hardened cement paste," in Proceedings of the 9th International Congress on the Chemistry of Cement, pp. 1485-1525, 1992.

[51] C. N. Mulligan, R. N. Yong, and B. F. Gibbs, "Remediation technologies for metal-contaminated soils and groundwater: an evaluation," Engineering Geology, vol. 60, no. 1-4, pp. 193-207, 2001.

[52] A. Pariatamby, C. Subramaniam, S. Mizutani, and H. Takatsuki, "Solidification and stabilization of fly ash from mixed hazardous waste incinerator using ordinary Portland cement," Environmental Sciences, vol. 13, no. 5, pp. 289-296, 2006.

[53] Q. Tang, X. W. Tang, Z. Z. Li et al., "Zn(II) removal with activated firmiana simplex leaf: kinetics and equilibrium studies," Journal of Environmental Engineering, vol. 138, no. 2, pp. 190199, 2012.

[54] X. He, H. Hou, and D. Zhang, "Study on cement solidification of municipal solid waste incineration fly ash," Environmental Pollution and Control, vol. 28, pp. 425-428, 2006 (Chinese).

[55] H. Liu, S. Liang, J. Gao et al., "Enhancement of $\mathrm{Cr}(\mathrm{VI})$ removal by modifying activated carbon developed from Zizania caduciflora with tartaric acid during phosphoric acid activation," Chemical Engineering Journal, vol. 246, pp. 168-174, 2014. 

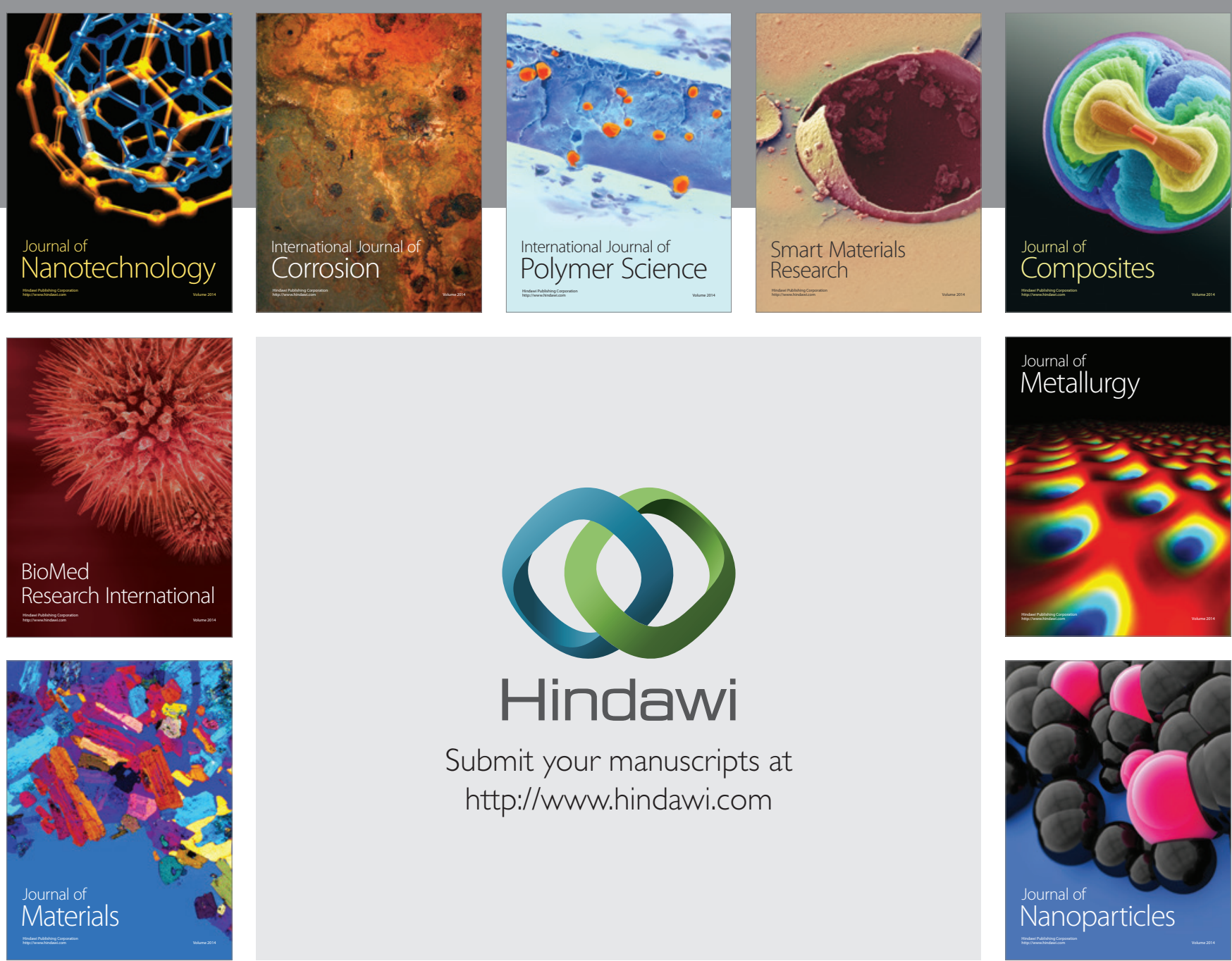

\section{Hindawi}

Submit your manuscripts at

http://www.hindawi.com

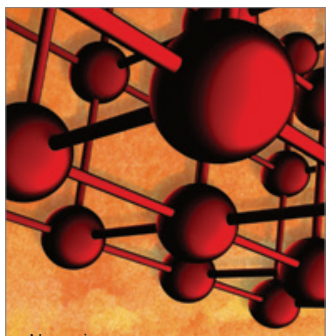

Materials Science and Engineering
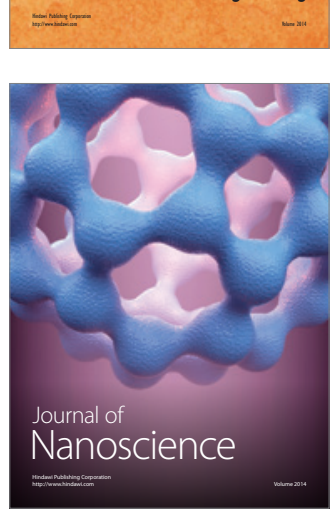
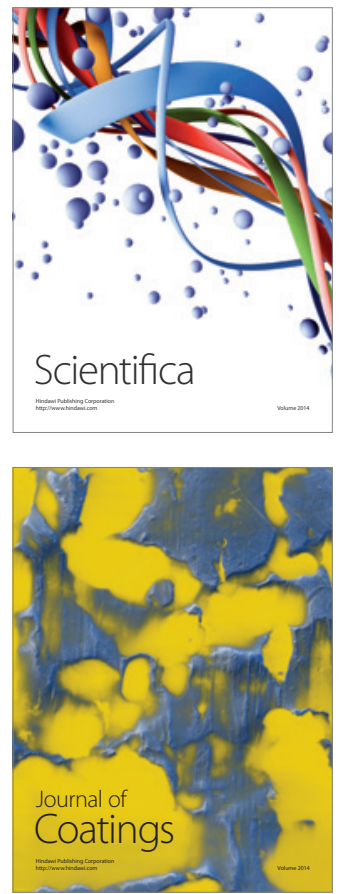
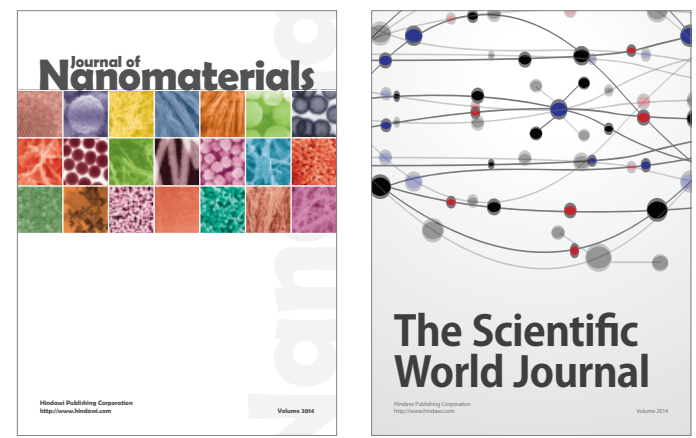

The Scientific World Journal
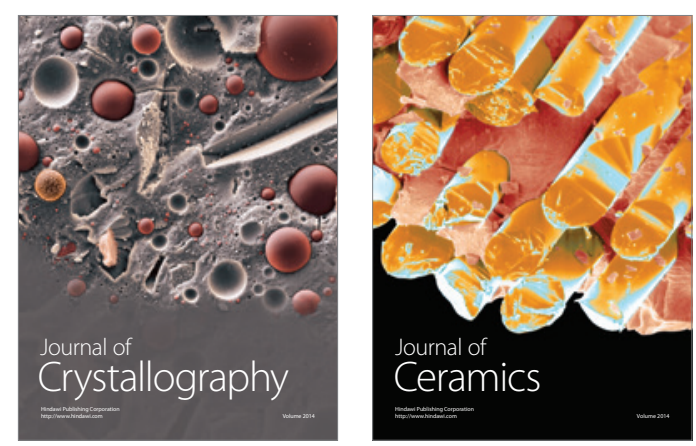
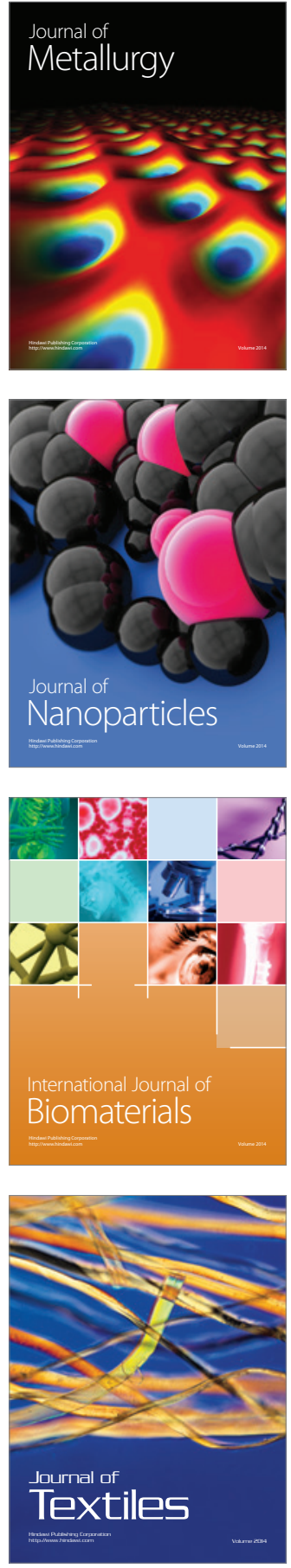